\title{
Productivity and quality of juices from different genotypes of 'Bordô' grape (Vitis labrusca) in the Vale do Rio do Peixe -SC region
}

\author{
Angélica Bender *iD, André Luiz Kulkamp de Souza², Vinicius Caliari², Cristian Soldi ${ }^{3}$, \\ Leocir José Welter ${ }^{3}$, Lírio Luiz Dal Vesco \\ $10.1590 / 0034-737 X 202168040008$
}

\begin{abstract}
The present study aimed to evaluate productive characteristics and the physical, chemical and sensory quality of juices elaborated from different clones of the 'Bordô' cv. produced in the Vale do Rio Peixe-SC region, in 2016/17. The 11 genotypes evaluated were identified as: G03, G07, G08, G10, G12, G13, G15, G16, G17, G18 and G19. At harvest, fruit production and quality were evaluated. The mean productivity of the 11 tested genotypes was $31.2 \mathrm{tha}^{-1}$, with a production of $18.7 \mathrm{~kg} / \mathrm{plant}$. Genotypes G13, G16, G19 and G08 showed higher productivity in tha ${ }^{-1}$ and kg/plant. G10 had the highest acidity. Genotypes G18 and G19 showed lower color intensity and phenolic compounds. Sensorially, genotypes G19 and G16 received lower scores for color, pleasant aroma and overall impression aspects. The 11 'Bordô' genotypes evaluated showed high productivity and favorable physical, chemical and sensory characteristics for the industrialization of juices in the Vale do Rio do Peixe-SC region, with the exception of the juices of genotypes G18 and G19, which showed little color, something that may end up mischaracterizing the 'Bordô' juices.
\end{abstract}

Keywords: clones; post-harvest quality; agroindustrialization; coloring.

\section{INTRODUCTION}

The production and commercialization of grape juices in Brazil has grown exponentially in recent years. Statistical data from the state of Rio Grande do Sul, the largest grape producer and processor in the country, show an increase in the destination of common and hybrid grapes for juice production (Mello, 2018). In the 2018 harvest, $50.0 \%$ of the grape produced was used for the production of juices and derivatives, a value higher than that of the 2016 and 2017 harvests, which remained between 45\% and $49.1 \%$, respectively (Mello, 2018). In the state of Santa Catarina there was also an increase in the production of grape juice in recent years, to the detriment of the production of table wines (Caliari, 2019). However, the state lacks the production of American and hybrid grapes, mainly of the 'Bordô' cultivar, which attributes color, structure and flavor, characteristic to wines and juices is appreciated by the consumer. In the 2018 harvest, $26.1 \%$ of the grape processed in the state of Santa Catarina came from Rio Grande do Sul and Paraná states (Caliari, 2019).

The increase in demand for raw materials for the industrialization of grape juices leads to the need for implementation and modernization of the vineyards, in addition to the development of cultivars that have short and long cycles to extend the harvest period, and that improve the color quality, aroma and flavor of the drinks (Mota et al., 2018). Currently, the main grape cultivars used in juice making in Brazil are 'Isabel', 'Concord' and 'Bordô'. The 'Bordô' cultivar is widely produced in Brazil, due to its rusticity and high color potential for the preparation of derivatives. However, this cultivar has cultivation restrictions in some regions due to

\footnotetext{
Submitted on July $28^{\text {th }}, 2020$ and accepted on January 09 th 2021.

${ }^{1}$ Universidade Federal de Pelotas. Departamento de Fitotecnia, Pelotas, Rio Grande do Sul, Brazil. bender.angelica.fruti@gmail.com

${ }^{2}$ Empresa de Pesquisa Agropecuária e Extensão Rural de Santa Catarina, Videira, Rio Grande do Sul, Brazil. andresouza@epagri.sc.gov.br; caliari@epagri.sc.gov.br.

${ }^{3}$ Universidade Federal de Santa Catarina, Curitibanos, Rio Grande do Sul, Brazil. cristian.soldi@ufsc.br; leocir.welter@ufsc.br; lirio.luiz@ufsc.br

*Corresponding author: bender.angelica.fruti@gmail.com
} 
physiological disorders that can significantly reduce its production (Miotto et al., 2014; Castilhos et al., 2016). In the south and southeast regions, the maturation period of the 'Bordô' grape coincides with the rainy season and, in certain situations, the cultivar does not reach a satisfactory ratio of soluble solids and titratable acidity (SS/TA) to produce quality juices. Brighenti et al. (2018) state that an alternative to circumvent production problems is the use of genotypes that are better adapted to growing conditions and that increase and maintain constant productivity.

Miotto et al., (2014) studied 12 different genotypes of 'Bordô' from a clonal selection program of the Minas Gerais Agricultural Research Institute (EPAMIG) in the municipality of Caldas-MG, with the objective of evaluating production and quality of fruits in subtropical wine-growing areas. The authors concluded that the genetic variability significantly influenced the productive behavior, and thus, indicated the 13-'Paco' genotype for being the most productive under the conditions studied. Brighenti et al., (2018) evaluated 11 of these same genotypes for productive and qualitative performance in the Vale do Rio do Peixe region, in the State of Santa Catarina. The authors concluded that the G13 and G16 genotypes are the most suitable for cultivation in the studied region, as they showed higher productivity, production stability and resulted in grapes with adequate quality for the production of wines and juices.

The two studies described above made it possible to validate the agronomic performance of the different 'Bordô' genotypes in two contrasting climatic conditions. However, no study is available regarding the quality of derivatives made from these genotypes. Considering that the adaptation of the fruits to the requirements of the industry to obtain a quality juice (color, flavor and aroma) is an essential factor for the selection of a genotype, being necessary to complement the information obtained in the field. Therefore, the objective of this study was to evaluate the components of grape productivity, aspects of physical, chemical and sensory attributs of juices made with 11 different genotypes of the 'Bordô' cultivar produced in the Vale do Rio Peixe region.

\section{MATERIAL AND METHODS}

The study was carried out during the 2016/2017 cycle, in a vineyard installed in 2008, at the Panceri winery, in the municipality of Tangará, in the Vale do Rio do Peixe region, in the state of Santa Catarina, Brazil (26 $16^{\circ} 17^{\prime \prime} \mathrm{S}, 51^{\circ}$ $10^{\prime} 25^{\prime \prime} \mathrm{W}, 870 \mathrm{~m}$ above sea level). The climate of the region, according to the Köppen-Geiger classification, is humid mesothermal ( $\mathrm{Cfb}$ ), that is, a constantly humid temperate climate, with no dry season and cool summer (Alvares et al., 2013). The mean annual temperature is $16.8{ }^{\circ} \mathrm{C}$, a maximum of $24.1^{\circ} \mathrm{C}$ and a minimum of $11.9^{\circ} \mathrm{C}$. The mean annual accumulated precipitation is $1,640 \mathrm{~mm}$ and the mean number of rainy days per year is 208 days. There is a mean of 17 frosts per year and the cumulative mean of temperatures below $7.2^{\circ} \mathrm{C}$ is 540 hours per year (Back et al., 2013).

The plant material used originated from a process of clonal selection from the 'Bordô' cultivar ( $V$. labrusca), carried out in EPAMIG and in a privately owned vineyard, in the municipality of Caldas, MG, Brazil ( $22^{\circ} 55^{\prime} \mathrm{S}, 46^{\circ} 23^{\prime} \mathrm{W}$ ) and reported by Regina (2004), referred to as genotypes in this work. The rootstock used was 'Paulsen 1103', with a 3.0 x 2.0 m spacing, with a trellis system and pruning was mixed (sticks and spurs). Cultivation treatments (pruning, fertilizing, sprouting, topping and phytosanitary treatments) were carried out by the company in accordance with technical recommendations.

The design used in the experiment was in completely randomized blocks and 11 genotypes were evaluated, namely: G03, G07, G08, G10, G12, G13, G15, G16, G17, G18 and G19. Each plot consisted of five plants with three replications. For the evaluations, the three central plants of each plot were considered.

Production data (kg/plant) was determined with an electronic field scale and productivity estimate $\left(\mathrm{t} \mathrm{ha}^{-1}\right)$ was based on planting density (1,666 plants ha $\left.{ }^{-1}\right)$ and the number of clusters per plant were obtained at harvest time. In the physical analyses, 20 clusters were randomly sampled per plot, to determine the cluster length $(\mathrm{cm})$, using a digital caliper. The cluster mass $(\mathrm{g})$ and the mass of 100 berries $(\mathrm{g})$, extracted at random from the base, middle and tip of the cluster, were determined with the aid of a precision analytical balance $(0.01 \mathrm{~g})$. The cluster compactness index $\left(\mathrm{g} \mathrm{cm}^{-2}\right)$ was determined by [(cluster mass)/(cluster length)2], proposed by Tello \& Ibanez (2014).

The juices were elaborated in the experimental canteen of EPAGRI - Agricultural Research and Rural Extension Company of Santa Catarina, at the Videira Experimental Station (Videira, SC/Brazil), using the hot extraction system. The procedure consisted of destemming and crushing the berries mechanically in a manual equipment, with the addition of a commercially resistant enzyme complex (Pectinex Ultra SP-L ${ }^{\circledR}$ ) at a concentration of $3 \mathrm{~g}$ $\mathrm{hL}^{-1}$. The must was heated in a stainless-steel container, in constant homogenization, for 20 minutes until reaching $50{ }^{\circ} \mathrm{C}$. After removing the heat, maceration was maintained for \pm 1 hour. Pressing was then carried out to separate the liquid in a hydrostatic press (for small volumes) and the extracted juice was stored in a cold chamber at a temperature of $\pm 1^{\circ} \mathrm{C}$ for 24 hours, to decant the solid 
particles. The following day, the juice was transferred and pasteurized at a temperature of $86^{\circ} \mathrm{C}$. The juices were filled in transparent $500 \mathrm{~mL}$ glass bottles, using 10 bottles per genotype. Three of these were chosen at random for the physical-chemical, colorimetric and bioactive compounds analyses (carried out in triplicate), with each bottle representing a repetition. The rest of the samples were used for sensory analysis. The storage was at room temperature and in an apropriate place for drinks (free of odors and excessive light), until the moment of the physical, chemical and sensorial analyses.

Chemical analyses of titratable acidity (TA), soluble solids (SS), and $\mathrm{pH}$ physicochemical content were carried out in accordance with Normative Instruction No. 24 of 09/08/2005 (Brasil, 2005). The SS was determined in a digital bench refractometer with automatic temperature compensation (QUIMIS ${ }^{\circledR}$ ) and the result expressed in ${ }^{\circ} \mathrm{Brix}$. The $\mathrm{pH}$ was determined by Meter AD1030® $\mathrm{pHmeter}$ and the TA determinations were performed by titrating the sample with a standardized solution of $0.1 \mathrm{~N} \mathrm{NaOH}$, adopting $\mathrm{pH}=8.2$ as the end point of the titration, and the result expressed in $\mathrm{mEq} . \mathrm{L}^{-1}$. The SS/TA ratio was determined by obtaining the quotient of the division between SS ( ${ }^{\circ}$ Brix) and TA in $g$ of tartaric acid per $100 \mathrm{~mL}$ of juice, according to the methodology proposed by the Office International de la Vigne et du Vin (OIV, 2009). The determination of the total reducing sugars $\left(\mathrm{g} \mathrm{L}^{-1}\right)$ of the juices was performed using the DNS method described by Maldonade et al. (2016), adapted for grape juice.

To evaluate the color of the juices, a spectrophotometer (Konica Minolta ${ }^{\circledR}$, model CM-5) was used, determining the $\mathrm{L}^{*}$ coordinate, which represents the sample's luminosity ( $\mathrm{L}^{*}=0$ black to 100 white) (McGuire, 1992).

The total polyphenol content of the juices was determined by spectrophotometry according to the FolinCiocalteu colorimetric method (Singleton \& Rossi, 1965) and expressed in $\mathrm{mg}$ of gallic acid (GAE) $\mathrm{L}^{-1}$. Absorbance measurements were performed using a Ray Leigh spectrophotometer model UV-2601. The total content of monomeric anthocyanins was determined using the differential pH method (Giusti \& Wrolstad, 2001) using buffer solutions of potassium chloride ( $\mathrm{pH} 1.0$ ) and sodium acetate (pH4.5), the results were expressed in mg.L $\mathrm{L}^{-1}$ of Cyanidin-3-glycoside. The antioxidant capacity was determined by DPPH according to the methodology described by Kim et al. (2002), and the results expressed in ì M TEAC. $\mathrm{mL}^{-1}$.

The sensory evaluation of the juices was performed through mixed quantitative analysis according to NBR 12994 (ABNT, 1994). The intensity of the attributes was evaluated on an unstructured nine-point scale, anchored at the ends with the words "low intensity" and "high intensity" for color, "unpleasant" and "pleasant" for aroma, "low" and "high" for acidity and sweetness, "little" and "much" for the sweetness/acidity balance. The overall impression was evaluated by subjective hedonic analysis with the extremes "I disliked extremely" and "I liked extremely". The understanding of the attributes and descriptors by the tasters was verified and evaluated during the selection and training of the tasting team. A group of 10 evaluators who signed the Free and Informed Consent Term, approved by the Ethics Committee of the Federal University of Pelotas under protocol CAAE 92226218.8.0000.5317, was selected. The evaluators received the samples $\left(20 \pm 1^{\circ} \mathrm{C}\right)$ in wine glasses encoded with three random digits, together with the evaluation forms.

Quantitative data were subjected to analysis of variance (ANOVA) and when treatment effects were detected, the means were compared by the Scott-Knott Tests at $5 \%$ probability of error, using the software R ( R Development Core Team 2018).

\section{RESULTS AND DISCUSSION}

The cultivation of different genotypes of the American vine cultivar 'Bordô' (Vitis labrusca L.) in the Vale do Rio do Peixe region, SC, presented relevant agronomic characteristics, in terms of yield components for the 2017/ 18 cycle, the eighth year of cultivation. The mean yield estimate observed was $31.19 \mathrm{t} \mathrm{ha}^{-1}, 18.7 \mathrm{~kg} /$ plant, mean cluster mass was $126.5 \mathrm{~g}$ and 148.1 clusters/plant (Table 1). Comparatively, the yield components of the genotypes of the 'Bordô' cultivar observed in the present work were higher than the mean values ( 15 to $20 \mathrm{t} \mathrm{ha}^{-1}$ ) obtained in cultivations in the Serra Gaúcha region (Giovannini, 2008).

However, it is worth noting that, among the 11 evaluated genotypes in the present study, the most productive were genotypes G13 with $38.2 \mathrm{t} \mathrm{ha}^{-1}(22.9 \mathrm{~kg} /$ plant), G16 with $37.06 \mathrm{t} \mathrm{ha}^{-1}$ (22.2 kg/plant), G19 with 35.4 t ha-1 $(21.1 \mathrm{~kg} /$ plant $)$ and G08 with $34.7 \mathrm{t} \mathrm{ha}^{-1}(20.8 \mathrm{~kg} /$ plant) $\mathrm{p}<0.05$ (Table 1). The cultivation of the same genotypes, evaluated in the present study, was also reported by Miotto et al. (2014), where the G13 genotype proved to be the most productive $\left(14.9 \mathrm{t} \mathrm{ha}^{-1}\right)$ in CaldasMG, in the south of Minas Gerais state, although the plants were conducted in a spreading system and were from the third to the fifth year of cultivation on average. High mean estimates, between 34.1 to $38.1 \mathrm{t} \mathrm{ha}^{-1}$ were also observed by Brighenti et al. (2018), with genotypes G08, G16, G19 and G13 and proved to be the most productive, in the sixth year and in the same cultivation location. An important factor to be noted is that, among the most productive genotypes, in the present study as well as those reported by Miotto et al. (2014) and Brighenti et al. (2018), refer to the cultivars 'Paco' (G13) and 'Bocaina' 
(G16). These cultivars have already been registered by EPAMIG and are included in the National Register of Cultivars, of the Ministry of Agriculture, Livestock and Supply.

In the present study, it was also observed that the largest and significant ( $\mathrm{p}<0.05)$ mean mass per cluster $(\mathrm{g})$ were observed in genotypes G13 (144.9 g), G19 (139.7 g) and G16 (134.8 g). And, regarding the mean mass of 100 berries, the G19 (356.4 g), G13 (347.4 g) and G18 (345.2 g) genotypes showed higher mean values and differed ( $\mathrm{p}<$ 0.05) (Table 1). It was also observed that, the mass of clusters and berries do not have a direct relation, as in the case of the G16 (320.3 g/100 berry) that did not follow the same mass ratio between cluster and berry. Miotto et al. (2014) observed the highest mean cluster mass with the cultivation of the G13 genotype, however, these authors did not observe a direct relation between the cluster mass and the berry either. For Brighenti et al. (2018), the G13, G16 and G19 genotypes also stood out in the cluster mass evaluation. However, according to the data from these authors, there is no direct relation between the mass of the cluster and the physical characteristics, number of berries per cluster and diameter of the berry.

As for the estimate of the number of clusters per plant, this varied between 126 to 165 clusters per plant for the eleven genotypes evaluated in the present study, nevertheless, no statistical differences were observed (Table 1). It is noteworthy, therefore, that the combination between the number of clusters and the mean mass of the cluster directly influences the productivity (kg/plant) of the tested genotypes. In this context, genotype G17 resulted in the lowest cluster mass $(99.8 \mathrm{~g})$, a factor that resulted in low productivity, even with the high number of clusters (162) per plant. Such pattern is observed in all genotypes that showed lower productive values.

For Santos et al. (2011), several factors are related to productivity. In their study, the authors showed that the production components are directly related to the microclimate regime, with emphasis on the growing season, autumn-winter in São Paulo, and by the cultivation of two Bordô genotypes ('Bordô' and 'Barberinha' selection). Among other factors, the expansion and improvements in Brazilian viticulture in recent years can be explained by technological advances, evident in the creation of new cultivars and development of techniques and systems for vine management (Camargo et al., 2011). Miotto et al. (2014) reported that there is a set of factors that point to the formation of deficient clusters, such as the occurrence of excessive rainfall during flowering, in addition to the genotype factor. Similarly, Mota et al. (2018) observed that the productive characteristics of the different cultivars tested such as the number and mass of clusters and respective productivity is genotype dependent, besides other factors such as the system of conduction and age of the vineyard.

Likewise, regarding the physical characteristics of the clusters in relation to the mean length and the mean cluster compactness index, there were no statistical differences between the genotypes in the present study (Table 1). When the mean length $(11.8 \mathrm{~cm})$ and the mean mass of the cluster are associated, this reflects on the mean cluster compactness of the berries $\left(0.90 \mathrm{~g} \mathrm{~cm}^{-2}\right)$ of each genotype.

Table 1: Productive components and physical characteristics of the cluster of different genotypes of 'Bordô' (Vitis labrusca) cultivated in the Vale do Rio do Peixe Region, SC, 2016/2017 cycle

\begin{tabular}{lccccccc}
\hline Genotype & $\begin{array}{c}\text { Productivity } \\
\left(\mathbf{t ~ h a}^{-1}\right)\end{array}$ & $\begin{array}{c}\text { Production } \\
(\mathbf{k g} / \mathbf{p l a n t})\end{array}$ & $\begin{array}{c}\text { Cluster } \\
\text { Mass }(\mathbf{g})\end{array}$ & $\begin{array}{c}\mathbf{N}^{\mathbf{0}} \mathbf{d e} \\
\text { Clusters/plant }\end{array}$ & $\begin{array}{c}\text { Mass of } \\
\mathbf{1 0 0} \text { berries }(\mathbf{g})\end{array}$ & $\begin{array}{c}\text { Cluster } \\
\text { length }(\mathbf{c m})\end{array}$ & $\begin{array}{c}\text { Cluster } \\
\text { Compactness } \\
\left(\mathbf{g ~ c m}^{-2}\right)\end{array}$ \\
\hline G13 & $38.2 \mathrm{a}$ & $22.9 \mathrm{a}$ & $144.9 \mathrm{a}$ & $158.0 \mathrm{a}$ & $347.4 \mathrm{a}$ & $12.4 \mathrm{a}$ & $0.94 \mathrm{a}$ \\
G16 & $37.7 \mathrm{a}$ & $22.2 \mathrm{a}$ & $134.8 \mathrm{a}$ & $165.0 \mathrm{a}$ & $320.3 \mathrm{~b}$ & $12.4 \mathrm{a}$ & $0.88 \mathrm{a}$ \\
G19 & $35.4 \mathrm{a}$ & $21.1 \mathrm{a}$ & $139.7 \mathrm{a}$ & $151.7 \mathrm{a}$ & $356.4 \mathrm{a}$ & $11.8 \mathrm{a}$ & $1.00 \mathrm{a}$ \\
G08 & $34.7 \mathrm{a}$ & $20.8 \mathrm{a}$ & $127.6 \mathrm{~b}$ & $162.7 \mathrm{a}$ & $316.7 \mathrm{~b}$ & $12.5 \mathrm{a}$ & $0.82 \mathrm{a}$ \\
G15 & $31.7 \mathrm{~b}$ & $19.0 \mathrm{~b}$ & $129.3 \mathrm{~b}$ & $147.3 \mathrm{a}$ & $322.7 \mathrm{~b}$ & $11.8 \mathrm{a}$ & $0.94 \mathrm{a}$ \\
G18 & $30.8 \mathrm{~b}$ & $18.5 \mathrm{~b}$ & $131.4 \mathrm{~b}$ & $141.3 \mathrm{a}$ & $345.2 \mathrm{a}$ & $12.0 \mathrm{a}$ & $0.91 \mathrm{a}$ \\
G10 & $29.7 \mathrm{~b}$ & $17.8 \mathrm{~b}$ & $124.9 \mathrm{~b}$ & $141.3 \mathrm{a}$ & $329.8 \mathrm{~b}$ & $12.0 \mathrm{a}$ & $0.88 \mathrm{a}$ \\
G17 & $26.9 \mathrm{~b}$ & $16.2 \mathrm{~b}$ & $99.8 \mathrm{~d}$ & $162.0 \mathrm{a}$ & $316.7 \mathrm{~b}$ & $11.7 \mathrm{a}$ & $0.74 \mathrm{a}$ \\
G12 & $26.9 \mathrm{~b}$ & $16.2 \mathrm{~b}$ & $122.9 \mathrm{~b}$ & $132.0 \mathrm{a}$ & $320.3 \mathrm{~b}$ & $11.5 \mathrm{a}$ & $0.93 \mathrm{a}$ \\
G07 & $26.1 \mathrm{~b}$ & $15.6 \mathrm{~b}$ & $123.7 \mathrm{~b}$ & $126.0 \mathrm{a}$ & $320.6 \mathrm{~b}$ & $11.4 \mathrm{a}$ & $0.95 \mathrm{a}$ \\
G03 & $25.9 \mathrm{~b}$ & $15.5 \mathrm{~b}$ & $112.8 \mathrm{c}$ & $137.0 \mathrm{a}$ & $314.7 \mathrm{~b}$ & $10.7 \mathrm{a}$ & $0.99 \mathrm{a}$ \\
\hline Mean & 31.2 & 18.7 & 126.5 & 147.7 & 332.4 & 11.8 & 0.91 \\
\hline CV $(\%)$ & 12.59 & 12.59 & 6.06 & 11.83 & 3.85 & 4.38 & 16.98 \\
\hline
\end{tabular}

*Mean of three replicates. Values followed by different lowercase letters, in the column, are significantly different by Scott-Knott test (5\%). 
Cluster compactness is a factor that mainly reflects the occurrence or not of fruit rot diseases during the ripening period. Therefore, when associated to the rain regime conditions of a crop, this may have a greater influence than the cultivation system and which, in addition to requiring a greater number of sprays, may result in a drop in productivity and anticipation of the harvest (Rombaldi et al., 2004). According to regression analysis, these factors also demonstrate that there is a strong linear relationship between the severity of the cluster rot versus the cluster compactness (Hed et al., 2009). However, some genotypes are more susceptible to fruit production problems, characterized by the fall of flowers or young fruits and which, according to the year of evaluation, leads to a wide variation in the number of berries per cluster (Brighenti et al., 2018).

In the analysis of the juices, all evaluated samples met the specification of Brazilian legislation regarding SS content, which establishes a minimum value of $14{ }^{\circ} \mathrm{Brix}$ (Brasil, 2018). The highest SS content was found in the juices of genotypes G08 and G16, differing from the others (Table 2). In a study carried out by Brighenti et al., (2018), the authors concluded that after an evaluation period of four harvests, G16 is one of the most suitable genotypes for the Vale do Rio Peixe-SC region since it presented quality grapes suitable for making wines and juices. Costa et al. (2019) found lower values (11.4 and $13.0^{\circ} \mathrm{Brix}$ ) than those found in the present study, in 'Bordô' juices produced in the south of Rio Grande do Sul. The authors attribute the low values to the steam extraction system. In the 'Bordô' juices evaluated by Bandeira et al. (2017), the values were quite similar to those of the present study (15 ${ }^{\circ}$ Brix).

The acidity of the juices is a result of the fixed acids present in the grape berry (Rizzon \& Link, 2006). Like sugars, acids are transmitted to the juice during preparation. The highest acidity was found in the G10 juices (132.13 meq. $\mathrm{L}^{-1}$ ), the opposite was found for G17 juices, which presented the lowest mean (115.33 meq.L-1 $)$ for this same variable. All the juices under study had acidity levels well above the minimum value established by law, which is 55 meq.L ${ }^{-1}$ (Brasil, 2018). High values of acidity are interesting from a gustatory point of view, mainly for the production of grape juices, since the sweetness is balanced by the acidity of the juice making it more palatable (Brighenti et al., 2018). These high values can be justified by the lower temperatures during the ripening of the grapes in the state of Santa Catarina, a factor that reduces the acidic degradation in the berries and, consequently leading to greater accumulation of organic acids in the juice.

The G08 genotype showed a higher $\mathrm{pH}$ value (3.34), differing significantly from all except for genotype G12
(3.33) (Table 2). These results were considered intermediate compared to those verified by Frölech et al. (2019) and Bandeira et al. (2017) for 'Bordô' juices produced in the Pelotas (RS) region, whose values were found to be 3.28 and 3.45, respectively. The chemical characteristics of grape juices are extremely important since they provide information on the quality and the factors that may interfere with their acceptability by consumers (Vilas Boas et al., 2016a). The $\mathrm{pH}$ has an influence on the color of the juices, since it acts on the way in which anthocyanins are present in these. According to Rizzon \& Meneguzzo (2007), the minimum value for the $\mathrm{pH}$ of grape juices varies from 3.00 to 3.10 . These values correspond to those of all juices evaluated in the present study.

The G12 juices had the lowest mean for total reducing sugars, differing from the G08 and G13 genotypes. The values ranged from 138.17 to 158.17 g. $\mathrm{L}^{-1}$, being above those found by Mota et al. (2018) in 'Bordô' juices (98.5 g.L $\mathrm{L}^{-1}$ ), though these were produced by another method (extraction pan) and in Caldas, MG. The low sugar content in grapes is one of the main limitations in the production of juices since this can lead to juices that are not very sweet and very acidic. Fongaro et al. (2016) explain that the discrepancies in the content of reducing sugars in the juices from different producing regions can be justified by the different soil and climate conditions, as well as by the technological treatments used in handling from the field until the final product.

For the SS/TA ratio, the G17 juices obtained a higher average, differing from the others, with the exception of genotypes G08 and G16. The lowest mean for this variable was found in G10, being the only one that had values below the 15 - 45 range mentioned by Mota et al. (2018) as desired for this variable. Vilas Boas et al. (2016b) also refer to the aforementioned range as a reference and explain that the ratio expresses the balance between sweet and acidic flavors. Treptow et al. (2016) evaluated juices from different grape cultivars, with 'Cabernet Sauvignon' juices showing values above 60 , and being described as sensorially unbalanced and with excessive sweetness.

The $\mathrm{L}^{*}$ values ranged from 25.4 to 59.5 for G17 and G19, respectively, indicating a significant difference in the luminosity of the samples (Table 2). It is therefore worth noting that the luminosity characterizes the degree of clarity of the color, indicating whether the samples are light or dark, high $\mathrm{L}^{*}$ values represent lighter colors, and the opposite indicates darker colors (black $=0$ to white $=$ 100) (McGuire, 1992).

G19 juices showed less intense coloring in relation to the other genotypes, followed by G18, corresponding to 
the results observed regarding the luminosity of the samples. A lower color potential can be a negative factor when choosing a genotype of the cultivar Bordô, since the juices of this cultivar are traditionally used in cuts with other varieties due to its high colorimetric potential (Miotto et al., 2014; Brighenti et al., 2018). Bandeira et al. (2017) evaluated juice cuts with 'Bordô' and 'Isabel', noting that the juices intensified the hue as the high percentage of 'Bordô' was maintained.

The lower coloring of the juices of the G18 and G19 genotypes can be justified by the lower content of total anthocyanins presented (Table 3). Anthocyanins are responsible for the pigmentation of the berries and, consequently, for the coloring characteristics of the juices (Vilas Boas et al., 2014). According to Malacrida \& Motta (2006), grape juice has little difference in the composition of anthocyanins in relation to fresh grapes, however, during juice processing, losses in the level of anthocyanins and coloration may occur. Such losses usually occur during the juice production process, such as heating, pressing, pasteurization and enzymatic treatments. In addition, when the juices are packed in

Table 2: Mean values of total soluble solids-TSS $\left({ }^{\circ} \mathrm{Brix}\right)$, total acidity-TA ( $\left.\mathrm{mEq} \mathrm{L} \mathrm{L}^{-1}\right), \mathrm{pH}$, total reducing sugars $\left(\mathrm{g} \mathrm{L}^{-1}\right)$, $\mathrm{TSS} / \mathrm{TA}$ ratio and luminosity $\left(\mathrm{L}^{*}\right)$ of juices elaborated from the different 'Bordô' genotypes grown in the Rio do Peixe Valley Region, SC, in the 2016/2017 cycle

\begin{tabular}{lcccccc}
\hline Genotypes & $\begin{array}{c}\text { Total Soluble } \\
\text { Solids }\left({ }^{\circ} \mathbf{B r i x}\right)\end{array}$ & $\begin{array}{c}\text { Total Acidity } \\
\left(\mathbf{m E q} \mathbf{L}^{-1}\right)\end{array}$ & $\mathbf{p H}$ & $\begin{array}{c}\text { Total Reducing } \\
\text { Sugars }\left(\mathbf{g ~ L}^{-1}\right)\end{array}$ & $\begin{array}{c}\text { TSS/TA } \\
\text { Ratio }\end{array}$ & $\begin{array}{c}\text { Luminosity } \\
(* \mathbf{L})\end{array}$ \\
\hline G16 & $15.9 \mathrm{a}$ & $125.4 \mathrm{~b}$ & $3.1 \mathrm{~d}$ & $161.7 \mathrm{a}$ & $16.8 \mathrm{~b}$ & $59.5 \mathrm{a}$ \\
$\mathrm{G} 08$ & $15.8 \mathrm{a}$ & $129.5 \mathrm{a}$ & $3.3 \mathrm{a}$ & $159.0 \mathrm{a}$ & $16.6 \mathrm{~b}$ & $50.5 \mathrm{~b}$ \\
$\mathrm{G} 17$ & $15.2 \mathrm{~b}$ & $115.3 \mathrm{c}$ & $3.2 \mathrm{~d}$ & $153.2 \mathrm{a}$ & $17.7 \mathrm{a}$ & $45.0 \mathrm{c}$ \\
G03 & $15.1 \mathrm{c}$ & $124.9 \mathrm{~b}$ & $3.2 \mathrm{~b}$ & $154.7 \mathrm{a}$ & $16.1 \mathrm{~b}$ & $37.5 \mathrm{~d}$ \\
G10 & $14.8 \mathrm{c}$ & $132.1 \mathrm{a}$ & $3.2 \mathrm{~b}$ & $142.8 \mathrm{~b}$ & $14.9 \mathrm{c}$ & $37.4 \mathrm{~d}$ \\
G13 & $14.8 \mathrm{c}$ & $121.5 \mathrm{c}$ & $3.2 \mathrm{c}$ & $154.8 \mathrm{a}$ & $16.2 \mathrm{~d}$ & $35.9 \mathrm{e}$ \\
G18 & $14.6 \mathrm{~d}$ & $122.5 \mathrm{c}$ & $3.2 \mathrm{c}$ & $158.2 \mathrm{a}$ & $16.0 \mathrm{~b}$ & $33.3 \mathrm{f}$ \\
G07 & $14.5 \mathrm{~d}$ & $126.6 \mathrm{~b}$ & $3.2 \mathrm{c}$ & $159.0 \mathrm{a}$ & $16.6 \mathrm{~b}$ & $32.3 \mathrm{~g}$ \\
G15 & $14.5 \mathrm{~d}$ & $125.6 \mathrm{~b}$ & $3.1 \mathrm{e}$ & $148.2 \mathrm{~b}$ & $15.6 \mathrm{c}$ & $28.5 \mathrm{~h}$ \\
G12 & $14.3 \mathrm{~d}$ & $123.1 \mathrm{~b}$ & $3.3 \mathrm{a}$ & $138.2 \mathrm{~b}$ & $15.5 \mathrm{c}$ & $27.3 \mathrm{i}$ \\
G19 & $14.2 \mathrm{~d}$ & $125.7 \mathrm{~b}$ & $3.1 \mathrm{~d}$ & $157.0 \mathrm{a}$ & $15.1 \mathrm{c}$ & $25.4 \mathrm{j}$ \\
\hline Mean & 14.9 & 124.8 & 3.25 & 152.6 & 16.0 & 37.5 \\
\hline CV $(\%)$ & 1.19 & 2.29 & 0.30 & 3.69 & 2.93 & 0.97 \\
\hline
\end{tabular}

* Mean of three replicates. Values followed by different lowercase letters, in the column, are significantly different based on Scott-Knott test $(5 \%)$.

Table 3: Total anthocyanins, total polyphenols and antioxidant activity of juices made with different 'Bordô' genotypes in the Vale do Rio do Peixe Region, SC, in the 2016/2017 cycle

\begin{tabular}{lccc}
\hline Genotypes & $\begin{array}{c}\text { Total anthocyanins } \\
\left(\mathbf{m g . L}^{-1}\right)^{*}\end{array}$ & $\begin{array}{c}\text { Total polyphenols } \\
\left(\mathbf{m g . L ^ { - 1 }}\right)^{* * *}\end{array}$ & $\begin{array}{c}\text { Antioxidant capacity } \\
\left(\boldsymbol{\mu} \mathbf{M}^{-L^{-1}}\right)^{* * *}\end{array}$ \\
\hline G17 & $85.0 \mathrm{a}^{* * * * *}$ & $2229.5 \mathrm{a}$ & $6030.0 \mathrm{a}$ \\
G03 & $84.0 \mathrm{a}$ & $1959.5 \mathrm{~b}$ & $5613.3 \mathrm{a}$ \\
G12 & $77.0 \mathrm{~b}$ & $2171.6 \mathrm{a}$ & $5850.0 \mathrm{a}$ \\
G16 & $73.0 \mathrm{c}$ & $1843.8 \mathrm{c}$ & $5883.0 \mathrm{a}$ \\
G10 & $67.0 \mathrm{~d}$ & $2133.1 \mathrm{a}$ & $4076.0 \mathrm{c}$ \\
G08 & $67.0 \mathrm{~d}$ & $1962.3 \mathrm{~b}$ & $3970.0 \mathrm{c}$ \\
G15 & $61.0 \mathrm{e}$ & $1736.6 \mathrm{~d}$ & $4923.0 \mathrm{~b}$ \\
G07 & $61.0 \mathrm{e}$ & $2009.0 \mathrm{~b}$ & $4726.7 \mathrm{~b}$ \\
G13 & $59.0 \mathrm{e}$ & $1529.7 \mathrm{e}$ & $4346.7 \mathrm{c}$ \\
G18 & $48.0 \mathrm{f}$ & $1325.9 \mathrm{f}$ & $2156.0 \mathrm{~d}$ \\
G19 & $34.0 \mathrm{~g}$ & $1160.6 \mathrm{~g}$ & $2290.0 \mathrm{~d}$ \\
\hline Mean & 67.6 & 182.4 & 4533.3 \\
\hline CV $(\%)$ & 2.71 & 2.69 & 6.00 \\
\hline
\end{tabular}

* Total anthocyanins expressed in $\mathrm{mg} \cdot \mathrm{L}^{-1}$ Cyanidin-3-glycoside

** Total polyphenols mg of gallic acid (GAE)/L

** Antioxidant activity ìM TEAC. $\mathrm{mL}^{-1}$.

**** Values followed by different lowercase letters, in the column, are significantly different by the Scott-Knott test (5\%). 
transparent bottles and exposed to light, there may be a change in the phenolic content during the storage period, mainly in anthocyanins, and a reduction in their color level (Burin et al., 2010).

The contents of total polyphenols verified in the present study varied from $1160.6 \mathrm{mg} . \mathrm{L}^{-1}$ to $2229.5 \mathrm{mg} . \mathrm{L}^{-1}$, with the lowest means presented by genotypes G18 and G19. The results of the present study are close to the values verified in a study carried out by Burin et al. (2010), which obtained results in the range of $1117.1 \mathrm{mg} . \mathrm{L}^{-1}, 3433.0$ mg. $L^{-1}$, for seven samples of commercial juices made with 'Bordô' grapes in the state of Santa Catarina. These authors observed that the statistical differences between the samples were due to the different extraction techniques used, for example, the type of extraction, time and temperature and the addition or not of enzymes, in addition to other factors related to grapes, such as ripening and cultivation practices.

Regarding the antioxidant capacity, it was observed that G17 had the highest mean with $6030.0 \mu \mathrm{M} . \mathrm{L}^{-1}$ while

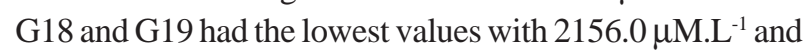
$2209.0 \mu \mathrm{M} . \mathrm{L}^{-1}$, respectively. Results that are consistent with those obtained by Dani et al. (2007) and Burin et al. (2010), who observed that there is a positive correlation between the content of total polyphenols and antioxidant activity.

Sensorially, the juices of the different genotypes showed similar behavior, showing a statistically significant difference only for the juices of G19 in terms of color intensity and G16 and G19 for pleasant aroma (Table 4), since they received the lowest scores for both variables. These lower scores may be responsible for the lesser appreciation of these juices by the evaluators because these same juices received the lowest scores for the overall impression variable. The variables acidity, sweetness and sweetness/acidity balance did not show significant differences for the different juices evaluated (Table 4). However, it is observed that the evaluators perceived acidity in a very similar way to sweetness, culminating in a perception of balance between these variables.

These results are corroborated by the correlations between sensory variables (Table 5). Overall positive and negative correlations were found for the treatments. The highest positive correlation coefficients occurred between pleasant aroma and overall impression $(r=0.68 ; \mathrm{p}<0.0001)$ and sweetness/acidity balance and overall impression ( $\mathrm{r}$ $=0.64 ; \mathrm{p}<0.0001)$. Positive correlations were also observed for color intensity and overall impression $(\mathrm{r}=$ 0.26; p 0.0051), as well as for sweetness and sweetness/ acidity balance $(r=0.32 ; \mathrm{p}<0.0005)$. For acidity and sweetness, a negative correlation was obtained $(r=-0.21$; $\mathrm{p}<0.0212$ ).

These correlations show that the increase in pleasant aroma and taste balance led to increases in overall impression values. During the stages of sensory analysis, the evaluator creates an expectation of the product, when verifying the aroma, the perceived sensations give an idea of what to expect in the mouth. When the appearance and odor are pleasant, it is believed that the taste will also be satisfactory, but when the perceived taste does not match the rest of the sensations, the product ends up being rejected, thus decreasing the overall impression mean (Bender et al., 2016).

Table 4: Sensory variables of color intensity, aroma and overall impression of juices made with different genotypes of 'Bordô' in the Vale do Rio do Peixe-SC Region, in the 2016/2017 cycle

\begin{tabular}{lcccccc}
\hline Genotypes & $\begin{array}{c}\text { Color } \\
\text { Intensity }\end{array}$ & $\begin{array}{c}\text { Pleasant } \\
\text { Aroma }\end{array}$ & $\begin{array}{c}\text { Overall } \\
\text { Impression }\end{array}$ & Acidity & Sweetness & $\begin{array}{c}\text { Sweetness/ } \\
\text { Balance Acidity }\end{array}$ \\
\hline G12 & $8.2 \mathrm{a}^{*}$ & $7.6 \mathrm{a}$ & $7.0 \mathrm{a}$ & $5.0^{\mathrm{NS}}$ & $5.7^{\mathrm{NS}}$ & $6.4^{\mathrm{NS}}$ \\
G03 & $8.0 \mathrm{a}$ & $6.9 \mathrm{a}$ & $6.3 \mathrm{a}$ & 5.7 & 6.4 & 6.4 \\
G08 & $8.0 \mathrm{a}$ & $8.0 \mathrm{a}$ & $6.4 \mathrm{a}$ & 4.9 & 4.9 & 5.5 \\
G17 & $7.9 \mathrm{a}$ & $6.8 \mathrm{a}$ & $6.4 \mathrm{a}$ & 4.5 & 5.9 & 5.9 \\
G16 & $7.9 \mathrm{a}$ & $4.3 \mathrm{c}$ & $4.9 \mathrm{~b}$ & 4.9 & 6.1 & 5.5 \\
G07 & $7.9 \mathrm{a}$ & $6.8 \mathrm{a}$ & $6.3 \mathrm{a}$ & 5.6 & 6.4 & 6.4 \\
G15 & $7.7 \mathrm{a}$ & $7.4 \mathrm{a}$ & $6.0 \mathrm{a}$ & 5.2 & 5.7 & 6.5 \\
G10 & $7.6 \mathrm{a}$ & $7.0 \mathrm{a}$ & $6.6 \mathrm{a}$ & 5.1 & 5.6 & 6.1 \\
G18 & $7.5 \mathrm{a}$ & $7.2 \mathrm{a}$ & $7.1 \mathrm{a}$ & 4.9 & 6.3 & 6.4 \\
G13 & $7.4 \mathrm{a}$ & $6.9 \mathrm{a}$ & $6.3 \mathrm{a}$ & 5.0 & 6.3 & 6.0 \\
G19 & $6.0 \mathrm{~b}$ & $5.4 \mathrm{~b}$ & $5.4 \mathrm{~b}$ & 5.4 & 6.4 & 5.8 \\
\hline Mean & 7.6 & 6.8 & 6.2 & 5.1 & 5.9 & 6.1 \\
\hline CV(\%) & 9.52 & 16.06 & 22.12 & 33.17 & 21.88 & 26.29 \\
\hline
\end{tabular}

* Mean of three replicates. Values followed by different lowercase letters, in the column, are significantly different by Scott-Knott test (5\%). NS Not significant by the Scott-Knott test $(5 \%)$. 
Table 5: Pearson's correlation coefficients and $p$ values between the dependent variables of grape juices of different varieties

\begin{tabular}{|c|c|c|c|c|c|c|}
\hline Variables & $\begin{array}{c}\text { Color Intensity } \\
\text { (1) }\end{array}$ & $\begin{array}{l}\text { Pleasant } \\
\text { aroma } \\
(2)\end{array}$ & $\begin{array}{c}\text { Acidity } \\
\text { (3) }\end{array}$ & $\begin{array}{c}\text { Sweetness } \\
\text { (4) }\end{array}$ & $\begin{array}{c}\text { Sweetness/acidity } \\
\text { Balance } \\
\text { (5) }\end{array}$ & $\begin{array}{c}\text { Overall } \\
\text { Impression } \\
\text { (6) }\end{array}$ \\
\hline \multirow[t]{2}{*}{ (1) } & & $0.22083^{*}$ & -0.08869 & 0.04270 & 0.076559 & 0.26488 \\
\hline & 1.000 & $(0.0204)^{* * *}$ & $(0.3568)$ & $(0.6578)$ & $(0.4266)$ & $(0.0051)$ \\
\hline \multirow[t]{2}{*}{ (2) } & & & -0.26559 & 0.30466 & 0.33431 & 0.68854 \\
\hline & & 1.000 & $(0.0050)$ & $(0.0012)$ & $(0.0004)$ & $(<0.0001)$ \\
\hline \multirow[t]{2}{*}{ (3) } & & & & -0.21956 & 0.03316 & -0.13598 \\
\hline & & & 1.000 & $(0.0212)$ & (0.7309) & $(<0.0001)$ \\
\hline \multirow[t]{2}{*}{ (4) } & & & & & 0.32659 & 0.35391 \\
\hline & & & & 1.000 & $(0.0005)$ & $(0.0001)$ \\
\hline \multirow[t]{2}{*}{ (5) } & & & & & & 0.64708 \\
\hline & & & & & 1.000 & $(<0.0001)$ \\
\hline (6) & & & & & & 1.000 \\
\hline
\end{tabular}

* Pearson's correlation coefficient. ** Values of $p$.

\section{CONCLUSION}

Higher productivity did not negatively affect the quality of the raw material for the production of juice and wine from the genotypes of the Bordô cultivar, which, in addition to the cultivars 'Paco' (G13), 'Bocaina' (G16), and G08 are promising, and can be indicated for cultivation in the Vale do Rio do Peixe-SC region.

Eight 'Bordô' genotypes evaluated showed favorable physical, chemical and sensory characteristics for the industrialization of juices in the Vale do Rio do Peixe-SC region. The juices of the G18 and G19 genotypes showed little color and bioactive compounds content, factors that may mischaracterize 'Bordô' juices. The juice of the G16 and G19 genotypes also obtained less sensory acceptance.

\section{ACKNOWLEDGEMENTS, FINANCIAL SUPPORT AND FULL DISCLOSURE}

The authors would like to thank CAPES, FINEP and FAPESC for the financial support and for the scholarship granted for the experiment and research.

The authors have no conflict of interests to declare.

\section{REFERENCES}

Alvares CA, Stape JL, Sentelhas PC, Moraes JLG \& Sparovek G, (2013) Köppen's -Climate classification map for Brazil. Meteorologische Zeitschrift, 22:711-728.

ABNT - Associação Brasileira de Normas Técnicas (1994) NBR 12994: Métodos de análise sensorial de alimentos e bebidas. Rio de Janeiro, ABNT. 2p.

Back AJ, Bruna ED \& Dalbó MA (2013) Mudanças climáticas e a produção de uva no Vale do Rio do Peixe-SC. Revista Brasileira de Fruticultura, 35:159-169.

Bandeira OS, Oliveira JS, Martinez JF \& Ferri CV (2017) Ordenação da preferência em suco e blends de uvas das cultivares Bordô e Isabel. Revista Brasileira de Viticultura e Enologia, 9:8-64.
Bender A, Costa VB, Rodrigues CM \& Malgarim MB (2016) Características sensoriais de sucos de uva elaborados com diferentes variedades e espécies. Revista da jornada de pós-graduação e pesquisa, 13:01-12.

Brasil - Ministério da Agricultura, Pecuária e Abastecimento (2005) Instrução normativa $\mathrm{n}^{\circ} 24$, de 8 de setembro de 2005 . Aprova o Manual Operacional de Bebidas e Vinagre. DOU, 20/09/2005, Seção 1, p.1.

Brasil - Ministério da Agricultura, Pecuária e Abastecimento (2018) Instrução normativa $\mathrm{n}^{\circ} 14$, de 8 de fevereiro de 2018. Complementação dos Padrões de Identidade e Qualidade do Vinho e Derivados da Uva e do Vinho. DOU, 09/03/2018, Seção 1, p.4-6.

Brighenti A, Allebrandt R, Munhoz B, Matos DP, Regina MA \& Silva AL (2018) Qualification of 'Bordô' grape clones in Vale do Rio do Peixe, in the state of Santa Catarina, Brazil. Pesquisa Agropecuária Brasileira, 53:800-808.

Burin VM, Falcão LD, Gonzaga LV, Fett R, Rosier JP \& BordignonLuiz MT (2010) Colour, phenolic content and antioxidant activity of grape juice. Ciência e Tecnologia de Alimentos, 30:1027-1032.

Caliari V (2019) Uva e vinho. Síntese anual da agricultura de Santa Catarina 2018-2019. Florianópolis, Epagri/Cepa. p.112-119.

Camargo UL, Tonietto J \& Hoffmann A (2011) Progressos na viticultura brasileira. Revista Brasileira de Fruticultura, Volume Especial:144-149.

Castilhos MBM, Maia JDG, Gómez-Alonso S, Del Bianchi VL \& Hermosín-Gutiérrez I (2016) Sensory acceptance drivers of prefermentation dehydration and submerged cap red wines produced from Vitis labrusca hybrid grapes. LWT - Food Science and Technology, 69:82-90.

Costa VB, Andrade SB, Lemos PLPK, Bender A, Goulart C \& Herter FG (2019) Physico-chemical aspects of grape juices produced in the region of Campanha Gaúcha, RS, Brazil (Southern Brazil). Bio web of conferences, 12:01-04.

Dani C, Oliboni LS, Vanderlinde R, Bonatto D, Salvador M \& Henriques JAP (2007) Phenolic content and antioxidant activities of white and purple juices manufactured with organically- or conventionally-produced grapes. Food and Chemical Toxicology, 45:2574-2580.

Rev. Ceres, Viçosa, v. 68, n.4, p. 310-318, jul/aug, 2021 
Fongaro C, Cavagnolli NI \& Spada PKWDS (2016) Avaluation of physicochemical parameters of grape juices produced in the Serra Gaúcha. BIO Web of Conferences, 7:01-08.

Frölech D, Assis AM, Nadal MC, Mello LL, Oliveira BA S \& Schuch MW (2019) Chemical and sensory analysis of juices and cuts of 'Bordô' and 'Niágara Rosada' grapes. Revista Brasileira de Fruticultura, 2:01-07.

Giovannini E (2008) Produção de uvas para vinho, suco e mesa. $3^{\text {rd }}$ ed. Porto Alegre, Renascença. 368p.

Giusti MM \& Wrolstad RE (2001) Characterization and measurement of anthocyanins by UV-visible spectroscopy. In: Wrolstad RE (Ed.) Current protocols in food analytical chemistry. New York, John Wiley and Sons. 13p.

Hed B, Ngugi HK \& Travis JW (2009) Relationship between cluster compactness and bunch rot in Vignoles grapes. Plant Disease, 93:1195-1201.

Kim D, Lee KL, Lee HJ \& Lee CY (2002) Vitamina C equivalente antioxidant capacity (VCEAC) of phenolics phytochemicals. Journal of Agricultural and Food Chemistry, 50:3713-3717.

Malacrida CR \& Motta S (2006) Antocianinas em suco de uva: composição e estabilidade. Boletim do Centro de Pesquisa de Processamento de Alimentos, 24:59-82.

Maldonade IR, Carvalho PGB \& Ferreira NA (2016) Protocolo para determinação de açúcares totais em hortaliças pelo método DNS. Brasília, Embrapa, p.32. (Comunicado Técnico, 81).

Mcguire RG (1992) Reporting of Objective Color Measurements. HortScience, 27:1254- 1255.

Mello LMR (2018) Vitivinicultura Brasileira: panorama 2017. Bento Gonçalves, Embrapa Uva e Vinho.7p. (Comunicado Técnico, 207).

Miotto LCV, Mota RV, Souza CR, França DVC, Dias FAN, Pimentel RM de A, Dal'Osto MC \& Regina MA (2014) Agronomic evaluation of 'Bordô' grapevine (Ives) clones. Scientia Agricola, $71: 458-463$.

Mota RV, Glória MBA, Souza BS, Peregrino I, Pimentel RMA, Dias FAN, Souza LC, Souza AL \& Regina MA (2018) Bioactive compounds and juice quality from selected grape cultivars. Bragantia, 77:62-73.

OIV - Organisation Internationale de la Vigne et du Vin (2009) Recueil des Méthodes Internationales d'Analyse des Vins et des Moûts. Paris, Organisation Internationale de la Vigne et du Vin. $368 \mathrm{p}$.
R Development Core Team R (2018) A language and environment for statistical computing. R Foundation for Statistical Computing, Available at: <http://www.R-project.org/>. Accessed on: June $13^{\text {th }}, 2020$.

Regina MA (2004) Analise comparativa da organização e metodologia da seleção clonal da videira na França e Brasil. Ciência e Agrotecnologia, 28:206-2012.

Rizzon LA \& Link M (2006) Composição do suco de uva caseiro de diferentes cultivares. Ciência Rural, 36:689-692.

Rizzon LA \& Meneguzzo J (2007) Suco de Uva. Brasília, Embrapa Informação Tecnológica. 45p.

Rombaldi CV, Ferri VC, Bergamasqui M, Luchetta L \& Zanuzo MR (2004) Produtividade e qualidade de uva, Cv. Bordô (IVES), sob dois sistemas de cultivo. Revista Brasileira de Agrociência, 10:519-521.

Santos AO, Hernandes JL, Pedro JRM.J \& Rolim GS (2011) Parâmetros fitotécnicos e condições microclimáticas para videira vinífera conduzida sob dupla poda sequencial. Revista Brasileira de Engenharia Agrícola e Ambiental, 15:1251-1256.

Singleton V \& Rossi J (1965) Colorimetry of total phenolics with phosphomolybdic-phosphotungstic acid reagents. American Journal of Enology and Viticulture, 16:144-158.

Tello J \& Ibáñez J (2014) Evaluation of indexes for the quantitative and objective estimation of grapevine bunch compactness. Vitis, 53:09-16.

Treptow TC, Franco FW, Mascarin LG, Hecktheeuer LHR \& Sautter CK (2016) Physicochemical composition and sensory analysis of whole juice extracted from grapes irradiated with ultraviolet C. Revista Brasileira de Fruticultura, 39:01-08.

Vilas Boas AC, Henrique PC, Lima LCO \& Decarlos Neto A (2014) Antioxidant activity, anthocyanins and organic acids content of grape juices produced in southwest of Minas Gerais, Brazil. Ciência e Agrotecnologia, 38:480-486.

Vilas Boas AC, Henrique PC, Lima LCO, Decarlos Neto A, Nassur RMR \& Lima RAZ (2016a) Atividade antioxidante e fenólicos totais em blends de sucos de uvas americanas produzidas no sudoeste de Minas Gerais. Boletim Ceppa, 34:15-26.

Vilas Boas AC, Nassur CMR, Freire JM, Carlos Neto A \& Lima LC (2016b) Quality characteristics and antioxidant activity of juices produced with irradiated grapes. Revista Brasileira de Fruticultura, 39:01-11. 